\section{EDUCATION AFTER THE WAR}

COME seventy delegates from twelve different $S$ countries attended the fourth general meeting of the Association of University Professors and Lecturers of the Allied Countries in Great Britain, held at New College, Oxford, during July 16-19, which included a conference of the Association of University Teachers. This was the largest and most important educational conference of the Allied Nations yet held in Great Britain, and the delegates were engaged in working out practical methods of post-war education in the occupied countries and seeking collaboration in this sphere with British and international bodies. The conference was welcomed by Sir Richard Livingstone.

At the opening session, at which Dr. S. A. Glaser (president) was in the chair, an address on the history of the University of Oxford was given by Prof. F. M. Powicke, regius professor of modern history at Oxford. Prof. Powicke said that Oxford has never ceased to be a place of debate and controversy. Oxford men have been the pioneers in constructive work for the betterment of the lot of mankind and for the furtherance of a wise imperialism and an international outlook upon affairs. Oxford has always been receptive, and in that it is characteristic of Britain. Now Oxford has to help bind up the wounds of learning but, whatever changes may come, Oxford will insist on being the same. Dr. Glaser remarked that when victory is won, Oxford traditions will inspire and animate university life all over Europe.

On July 17 the conference divided into various sections to discuss such subjects as collaboration with British scholars and with international bodies, reconstruction of science and learning in the occupied countries, post-war education of youth and future collaboration between the universities of Allied. Countries in law, science, technology, economy, modern humanities, history, medicine and information for students.

Sir William Beveridge, master of University College, and Lady Beveridge, who have just returned from a visit to the United States, received the members of the conference at University College on July 17, when they gave a brief impression of their visit to America. Sir William said he looks forward to the days when meetings of professors from many coun. tries would be held in every country instead of one or two centres.

Sir Richard Livingstone, president of Corpus Christi College, extending a welcome to the delegates, said that they were welcoming men and women, eminent each in his own branch of learning, ministers of wisdom, knowledge and truth. "But we welcome something more-a fortitude, endurance and faith in great adversity less often required of scholars, which has not been required of us. We wish to pay homage to that; we hope we shall not forget the example you have shown us ; for the exiled scholars of Europe have enriched the history of scholarship with something even greater than learning." The lack of a common language and of a common faith, he said, are great obstacles which should be surmounted. "Many stones need to be set into the foundations if the building of international friendship is not to be swept away by the next big flood that comes. Economic agreements, political understandings, personal friendships and mutual intercourse are among them. But these are not enough by themselves. The only mortar that can hold them together is a common faith. Universities absorb themselves in their various specialisms, and ignore the question of conduct and of the beliefs from which conduct springs, as if these were no part of their business. If so, we are ignoring the centre of the problem and gravely limiting our contribution to its solution. I would plead that we regard it as very much our business, and know that I shall plead to sympathetic ears, for it is not your knowledge or your studies that have inspired and sustained you during four black years-it is a spiritual force, a faith."

\section{Aims of the Association}

Dr. Glaser spoke of friends and colleagues in the occupied countries, and said that those present would wish to confirm most solemnly their unity and solidarity with them and to send to those still alive words of sympathy and belief in their liberation. Speaking of the foundation of the Association, he emphasized the encouragement and help they have received from their British colleagues. The Associa. tion comprised 249 members and two guests, and now represents seventeen countries. One of their main tasks, perhaps even the reason and justification of their formation, is the reconstruction and rehabilitation of the university life in the occupied and invaded countries when the War ends. A special section has been formed to deal with the problem and is working in close collaboration with the Committee on Post-War Education of the British Association.

The Association's second aim is contact and collaboration with the Anglo-Saxon scientific world. Prof. Glaser spoke of their collaboration with the British universities and said they have met every. where great friendliness, understanding and hospitality. He mentioned the idea of an international university, an Allied academy of medicine arid an international university institute, which would be considered as a centre of university education, with a special information and registration office and a department for comparative education. "If the only result of our present work and endeavour would be the fact that we came together and succeeded in formulating a common basis for collaboration, this one fact would be a remarkable achievement and of far-reaching consequences."

\section{Maintenance of European Civilization}

Dr. Gilbert Murray said they had a common aim that united them far beyond victory in the War and the restoration of national freedom; there is the immense and inescapable task of maintaining European civilization. "We Europeans are trustees for the human race of a great treasure-a treasure built slowly up by the efforts of the human souls in Greece, Rome and Jerusalem, and in the free nations of modern times. People like you and me must see that it is not lost. War is deadly to a civilization like ours. A Nazi victory would utterly destroy it. You and I can do something for the material side, but the intellectual is our special and obvious duty, and I am sure that no intellectual restoration is worth much which does not carry with it a moral restoration as well."

The White Paper of the Hot Springs Conference on the organization of the agriculture and food supply of the world and the report on the transition from war to peace economy just published by the 
Economic and Financial Organisation of the League of Nations, he added, show that, appalling as the post-war condition of Europe is likely to be, the United Nations have means of dealing with it such as have never been equalled or approached in the world before, and, so far as we can judge, the present leaders of the nations are firmly resolved to use them. He reminded his audience that as university teachers of the Allied Nations, they will have great material difficulties to contend against, but he sees no reason to expect such obstacles as would make it impossible for them to carry out their obvious duty-to keep alive the intellectual and artistic culture of Europe.

\section{Post-War Plans}

Prof. A. Sommerfelt, in dealing with the future of the Association, referred to the need for maintaining and extending its aims. He suggested that the Association should become an international organization, and that as enemy-occupied countries are liberated university professors and lecturers of those countries should be invited to join. Prof. Sommerfelt also suggested considering the appointment of a permanent secretary and secretariat, and urged the need for linking up with the international educational organizations which will be set up after the War.

The conference considered reports from the various sections which had been at work on the possibilities of setting up an educational clearing house for Europe. The law section was asked to prepare a list of English law books which would constitute a working law library for universities on the Continent. The history section had discussed the possibilities of preparing a handbook of suggestions for teachers dealing with the problems of objective history, a text-book of world history for secondary schools, and a short history of the war, starting from January 1 , 1938. The science section particularly emphasized the need for establishing an international body for the collection and co-ordination of information concerning inventions and discoveries.

Prof. Jean Timmermans, of Belgium, was elected president of the Association for the ensuing year.

\section{International University Conference}

The members of the Association of University Professors and Lecturers of Allied Countries took part, on July 19, in a meeting of the International University Conference, held under the auspices of the Association of University Teachers. Dr. Gilbert Murray presided.

Prof. Stefan Glaser, Polish Minister to Belgium and Luxemburg, speaking of the Association of the University Professors and Lecturers of Allied Countries in Great Britain as a permanent post-war organization, said they are now trying to elaborate the final statutes of the Association. The Association will probably be transformed in due course into an International Association of University Professors, in order to give colleagues from neutral countries the opportunity of joining the Association as full members. The definite organization of the Association will be postponed until after the War, when their colleagues from the occupied and invaded countries will be able to express their views on the matter. Until then the Association will be open unconditionally to scholars from Allied countries, and its seat will probably be Great Britain.

The Association will endeavour to protect the professional interests of university teachers, and this will be not only in their individual or personal interests, but also, and perhaps above all, in the interests of science and learning, with the object of assuring the most appropriate conditions and atmosphere. It will also deal with all matters and problems of interest and value to the object and aim of their endeavours, namely, science and research work.

In his opinion a true intellectual solidarity, a spiritual understanding based on mutual confidence and friendship among scholars, is not only the best pledge for the progress of culture and civilization but also for a political understanding, for a wise community of their countries and their people, and therefore for the security of peace and order in the future.

Prof. R. J. Tabor (Great Britain) introduced a proposal, which was agreed to, that the reconstructed International Association should function as a clearing house and an information centre on university affairs. Another proposal, that it should be a function of the International Association to safeguard the freedom and professional status and interests of university teachers, introduced by Prof. S. Brodetsky (Great Britain), was carried.

\section{An International Institute}

Agreement was also reached on a further proposal that the International Association be invited to take over the functions of the International University Conference. This proposal was introduced by Prof. R. C. McLean (Great Britain), formerly secretary of the International University Conference.

Prof. Stefan Glaser introduced a proposal that the International Association should be asked to take steps towards the creation of an International University Institute. The Institute would serve as an information and registration centre and would deal with such problems as exchange of teachers, exchange of students, research work in foreign countries, pro. grammes of studies, inter-validization of diplomas, standard text-books and international congresses and conferences. It would also, he suggested, have a school of comparative education, the aim of which would be the facilitation of specialization and the provision of experts to the respective universities.

This proposal was also agreed to, and the conference than expressed its general approval of the constitution and aims of the proposed International Association of University Teachers.

\section{An International Language}

The conference concluded with comments on some factors which hinder the development of international relations, and Prof. A. Sommerfelt (Norway), speaking of the language difficulty, said the future international organization of university teachers ought to draw the consequences of the events they were passing through. It ought to recognize only English and French as its official languages.

Prof. J. Timmermans (Belgium) agreed that the English language would play an important part in the future, but felt that it is essential to go ahead with research work with a view to the creation of an artificial international language. International trade and scientific intercourse require a language which is simple as well as precise and invariable. An artificial language is as necessary in that connexion as the notes used for music. 